\title{
European Integration: one electoral promise not taken
}

\author{
Ilda Rusi, \\ PhD CanD. European University of Tirana \\ ildarusi@yahoo.it
}

\begin{abstract}
"The process of European Union membership is a national objective, in view of the democratization and transformation of the Albanian society, in accordance with the values and principles of the United Europe". This sentence is taken from the Official Site of the Prime Minister of Albania. This message but expressed in other words seems to be there standing since 1992, when in Albania for the first time was articulated the desire for national integration of the country. After more than twenty years, the question that concerns me mostly is that why my country is not part of the big European family? What happened in these twenty-two years to prevent this process or to accelerate it? The first thing that comes to my mind after the last rejection candidate status on December, last year, is that this is a promise that none of the Albanian government has not yet managed to achieve. On my opinion, this process is strictly associated with the willing of all determinant political actors to collaborate and to manifest democratic political culture through dialogue. European integration is a slogan used in every political campaign, as a key element of the political agenda all political parties but in. It helps a lot during the electoral campaign but unfortunately we are still waiting for. Thus, I think that the integration process is not related only to the Albanian desire for participating in the EU, but mostly to the political class attitude. It is true that every time that the government does not achieve the candidate status, the political parties to blame each other for retarding the integration process. Even though, different scholars emphasize the role of EU in the process of integration, I believe that the country's democratization is a process strongly related to the political elite performance and the way they manifest politics. Albanian political class must admit that the real problem in this process is the way that it makes politics and how it makes political decision. In this article, I argue that the European integration is a process which can be successful only if all political parties in Albania understand that this is an obligation that they have with Albanian citizens and that cannot be realized if all of them are not committed to. This ambitious goal can be achieved only when the EU priority reforms are going to be established and in Albania there are going to operate functional and free institutions based on meritocracy and democratic system of operation far away from politics.
\end{abstract}

Key words: integration, democratization, political dialogue

\section{Introduction}

In order for a state to be part of the European Community, it is needed much more than the desire to be part of it or the geographical location. The European Union is an organization that brings several benefits but it requires a certain standard of sustainable economic, political and legal development. Albania, as well as other Balkan states of South-East Europe, is trying to meet these standards and has begun the EU adaptation process. This process is a combination of internal and external whose aim is to achieve this major objective.

On the one hand we have the EU which external pressure to implement reforms that will bring even more Albanian government with European standards. On the other hand, we have local commitment to achieve these objectives that will enable the fulfillment of these standards. These two elements are part of the same process which cannot function if one side of it is not operating properly.

Unlike some scholars who emphasize the imperative of European and the skepticism that EU has in regard to Albania (Hoffmann, Elbasan), I think that the most important element to analyze in this process is what is happening with commitment of Albanian political spectrum in relation to this process.

In this paper, I argue that the process of integration is a complex process dominated mainly by the efforts and commitment of endogenous factors. Although Brussels may have more favorable policies for the membership in the EU country (as was the wave of enlargement in 2004) and a clearer idea of how to shape local policy making, applying other tools and instruments for the democratization consolidation, the Albanian state must necessarily in the first place prove that it is ready for such commitment. Ultimately, the process of integration is strictly associated with the process of democratization of the country and the successful completion of the transition phase which would generate the consolidation of the democratic, legal and constitutional state. Democracy cannot be imported, but there must be all 
ISSN 2411-9563 (Print) ISSN 2312-8429 (Online)
European Journal of Social Sciences Education and Research
September-December 2014

Volume 1, Issue 2

elements for it to be strengthened and institutionalized within the country. Only in this way Albania can become an EU member state and enjoy the rights and privileges that this process involves. This goal can be achieved when Tirana (and here I refer not only to the state apparatus and government institutions, but to all political forces and political elites in general) to take this commitment seriously and produce broad-based consensus that would allow the implementation of consensual reforms and what is most important strengthening of independent institutions. This national strategy must be a long-term strategy and must involving all necessary conditions for the generation of political and institutional structures that can preserve democratic institutions based on the rule of law.

This paper aims to analyze the political factors that have returned to drawback of this process of democratization and integration. Referring to the EU conditionality, I emphasize the inability of the Albanian political class for cooperation and implementation of consensual reforms. Therefore, first of all, I think it is very important to understand what are the requirements that the EU has in confront to Albania. In the second part of the paper, I discuss how Tirana is committed in achieving these objectives and goals. This comparative approach will enable us to highlight which part of this mutual cooperation is not operating properly.

\section{EU: the most dominant external factor in the integration process}

International comparative democratization literature emphasizes the external factor in the transition phase. Huntington will determine the third wave of democratization dominated by the role that external factors have on the process of democratization through reform initiatives (Huntington, 1991). In the same line, Schmitter, defines the role of external actors as the dominant phase of democratization. He points out that these factors have the ability to launch and being implemented reforms in transition countries (Schmitter, 1996). Through economic assistance and political support, the external factor influences directly in domestic politics and in opening the way to the consolidation of democracy and the rule of law.

In the Central and Eastern Europe countries, the role that EU played in the democratization process through its conditionality policies is unquestionable. Heather Grabbe (2002) analyzes how the EU uses its terms to countries aspiring to integrate, to influence the choices they make. The EU has many sources of influence that affect the policies and institutions of the aspirant countries through aid and assistance instruments that are so highly desired by these countries (Kubicek, 2003).

Conditionality is one of the most dominant elements to explain the effectiveness of the EU in support of reforms towards democracy and market economy. The EU initiatives used to influence the process of reforming the institutions and policy transformation in the countries of Central and Eastern Europe can be categorized as: (1) access to the negotiations; (2) assistance in legal and institutional drafts; (3) aid and technical assistance, (4) counseling about domestic policies; (5) monitoring of the implementation process (Grabbe, 2002, 257). Definitely, we can say that the five elements mentioned above are applied also in the case of Albania, including financial assistance as well as a very important element. We must take in consideration the fact that $\mathrm{EU}$ is the main source of financing in this country.

Specifically, the EU is present in Albanian policymaking starting in the early 1990s when the country began the long process and apparently infinite transition. The first official relations began in 1992, when Albania signed the cooperation agreement between the EU and Albania. This agreement meant that Albania could benefit from the Phare program, which was a financial instrument to the countries of Central and Eastern Europe in their preparatory phase towards integration because these countries have applied for membership status. These funds will go towards political and economic institutional reorganization in order to have a smooth and gradual transition (expansion of the European Commission).

As for the rest of the countries of Central and Eastern Europe, in 1997, the EU introduced economic and political conditions which necessarily had to be completed to launch the country's EU integration. In this context, the European Commission and the World Bank elaborated a plan for economic recovery and growth that will ensure a successful transition (Enlargement of the European Commission).

In 1999, the EU will be launching SAP (Stabilization and Association Process) for five countries of South-East Balkans, including Albania. In the same year, Albania approved the Preferential Trade Autonomous Agreement with the EU and other Balkan countries, which was valid until 2011. This proposal offered to Balkan countries duty-free access to all European markets for their products. It provided economic integration with the EU countries and created premises for democratization of Albanian economic institutions. 
In 2000, the two summits, Feira and Zagreb Summit underlined the importance of PSA in the integration process. In particular Feira Summit will declare that all SAP countries could become EU candidate countries. Both summits gave a special importance and defined SAP as the only way toward integration process.

In this context, in 2001 the EU presented the CARDS program, which was designed specifically to SPA countries. Therefore, the European Commission, as for the other countries that had signed the SPA, recommended the initiation for the negotiation of the Stabilization and Association Agreement with Tirana. Shortly after this initiative, in Tirana, the first meeting was held under the SAA. After that, the European Council urged the Commission to prepare a strategic document for Albania. Negotiations and guidelines were prepared based on the reflection on the Stabilization and Association Report.

Evaluating Tirana's commitment, in 2003 the EU formally started the negotiations for a SAA with Albania. In June 2006, the SAA was signed in Luxembourg. In the following year came the IPA, Pre Entry assisting tool, which included new instruments for pre-EU accession. On 1 April 2009, Albania was officially introduced at SAA. This act was soon followed by Albania's application for candidate status. This request was rejected by Brussels (Expansion of the European Commission).

The main objective of the SAA is to assist Albania in the process of democratization and the consolidation of democratic mechanisms. It includes a specific agenda with detailed reforms, which are assessed as a priority by the EU. SAA assistance as part of Brussels strategy, is a political tool used by the European Commission to achieve several objectives simultaneously. According to the European Commission, these objectives are:

1. The PSA is designed in the context of preparation SEE country moves closer to European standards. It will assist in the transition process to gradually achieve full integration in the EU.

2. EU is committed to assist the Government and its efforts to consolidate democracy, which means the existence of the rule of law.

3. SAP is responsible for assisting the country to achieve reforms in institutional and administrative dimensions. It is also responsible for assisting in the consolidation of a strong system of public administration and judicial system (European Commission 2001).

European conditionality will help the government to address the most problematic areas such as organized crime and corruption. It will assist in the implementation of the rule of law, maintaining political dialogue, consolidation of the electoral code, and the development of civil society (European Commission 2003).

On 15 December 2010, the European Parliament and the Council of Europe gave the chance to Albania to benefit from visa liberalization of Schengen regime. It placed a monitoring mechanism to ensure continuity of implementation (European Commission, 2001, 5).

As evidenced above, the EU has been very present in the progress and political development of the country. At this point, I agree with Elbasani who argues that if it was not for the EU conditionality, political development in Albania would have had another trajectory. And in fact the moments when the political elite in the country has been able to provide not only democratic development, but also has led to chaos (do not forget pyramid schemes and riots of 1997), the EU has intervened to restore peace and has assisted in the state recovery.

\section{EU conditions for membership}

But is it enough just EU engagement in the process of consolidating democracy and the generation of the rule of law? In the case of Albania, the EU has used the policy of "carrot" \& "stick" (Grabbe, 2002) which means on the one hand through technical and financial assistance toward Tirana Brussels tempts the path of development but on the other hand, whenever the government did not properly made the "homework", Brussels condemns it by denying deeper integration (recent denial of the candidate status).

In this context, what bothers me mostly is not how the EU tempts Tirana towards European commitments, but how Tirana is not taking seriously its obligations in this negotiation.

In this part of the paper I will focus on the EU conditions that Albania has to achieve in order to start negotiations for EU membership. Therefore, I see as very important to analyze what are these criteria and to analyze how closer or far Albania is at least in this process. This comparison will enable us not only the clarity of what is expected from the Albanian side but also identifying gaps and achieving real reform of European targets. 
The European Union is an organization based on the values of democracy and rule of law. To be a member state of the European Union, the candidate country must have necessarily reflect those values and prove that it has the necessary institutions to protect these values (Featherstone, 1998).

The EU has recorded since 1993 which should be the basic criteria for a country that can initiate the integration path. Copenhagen criteria explicitly define three prior conditions necessary for membership. They consist of the political criteria, economic and legislative. In more detailed form, in meeting the political criteria consists of several basic elements that a state is called a consolidated democracy, namely a functional democratic government in which citizens have full access to all levels of policymaking, including free and fair elections fair; rule of law, respect for human rights comfort all international conventions on human rights; and respect for and protection of minorities.

The second criterion consists on the country's macroeconomic indicators. Specifically, an aspiring country must have a functioning market economy and whose products have the capacity to cope with competitive pressure and European market forces.

Legislative aspect has to do with the ability to adjust and incorporate the national legislation with the acquis communautaire and all treaties and agreements that constitute it (Presidency Conclusions, 1993).

In a more specific way, in the context of the SAA at the third meeting of the Stabilisation and Association Agreement between the EU and Albania, in Brussels on 19 July 2011, was clarified and reaffirmed the twelve key priorities which were reflected in Opinion the European Commission on Albania. Specifically, these priorities focus on the stability of institutions guaranteeing democracy, strengthening the rule of law, judicial reform, the fight against organized crime and corruption, electoral reform, public administration reform, and protection of human rights including property rights. All these elements relate to the first Copenhagen criterion, therefore, in the following analysis I will only focus in this criterion. Not because two other criteria are less important, but keeping in mind the modernist approach, I believe that democratic institutions will facilitate the consolidated socio-economic development which is guaranteed in itself by these independent institutions.

The Council urged political parties to overcome political disagreements and establish a constructive and sustained dialogue in order to ensure correct functioning of parliament. It estimated that the negotiation will only start when it was verified that the country was seriously committed in meeting the criteria and in particular to these key priorities (Third Meeting of the Stabilization and Association Council between Albania and the EU, 2011).

Meanwhile, in parallel with the political assistance of Brussels, Albania continues to receive financial assistance under IPA in two important respects: (i) transition assistance and institution building (II) cross-border cooperation with a total value of 82 million Euros per year 2013 (European Commission report on Albania, 2013).

\section{Albania's commitment}

Although whenever it comes to integration, all political forces without exception define it as a necessity for the country's future, it seems that the steps with which Albania is moving toward it are relatively slow. Since 2011, the country is trying to achieve twelve priority conditions set by Brussels as essential to any discussion regarding the status of candidate country. Therefore, any premature application is not only unhelpful but on the other hand means more wasted consumed energies.

Specifically, if we analyze the political situation of the last two years, following the 2011 local elections, the political situation in the country is associated with a pronounced lack of dialogue, coupled with a strong clash between the two main mainly DP and SP not only verbal but also physical (January 21 incident). Masquerading of insults, sterile debates and political arrogance that has dominated parliament is failing to take proper form to achieve the necessary reforms. In this context, it is very interesting to analyze how the European Commission has assessed Albania in the last year.

Following the Copenhagen Criteria rankings, I will first see what is done to get closer to the European approach. The European Commission's annual report for 2013 Albania determines that the country has moved slowly toward the realization of institutional reform. Specifically, although the recent elections are assessed as relatively democratic, the report emphasizes mainly in the polarized political climate that has accompanied the pre and post election period. It admits that there was a smooth transition of power between the two main forces, this convincing result as a consequence of the Alliance for European Albania.

General elections were preceded by a tense political climate that has threatened our administration of elections. Although the elections were competitive, I must admit that last year's turnout was lower, 53.6 percent. Even these elections as well 
as others recorded some progress. However, OSCE / ODIHR reaffirmed recommendations for the upcoming elections (Report, 6-7).

Regarding the functioning of parliament, the report identifies some reservations. Although it must be admitted that there were some sporadic moments of cooperation during fall 2012 and May 2013, the parliament was dominated by an aggressive climate policy.

As for the government, the report concludes that it is moving slowly in terms of the strategic implementation of the key priorities proposed by Brussels. Also, there is not a clear coordination among the Ministry of Integration and other ministries.

With regard to local government, decentralization of administrative and territorial reforms have not progressed, but even though the law for urban plan was approved in April 2012, there are obvious problems in its implementation. Obviously the more politicized debate over compensating's Municipal some regional authorities have impacted negatively on the effectiveness of local authorities limited their role. Therefore, the report sees as very important constructive debate between the two levels of government as well as attendance in the decentralization reforms path and dialogue with civil society.

The most important part of this analysis, is much debated in public administration reform, which was one of the main recommendations of the EU and one of the key elements needed to get the candidate status. Public administration reform was adopted in May of last year the civil service law. This was an important step towards de-politicization of public administration which was radically removed whenever the central government changed. The law which came into force in October 2013, is essential in building a public administration professional, effective and based on meritocracy. The purpose of this law is to create a legal context which consists on the inclusion of independent institutions and local government units. It provides a clear classification of civilian officials; it creates an optimal management system and administration body and it creates all the prerequisites for a transparent system of hiring and promotion. This law repeals the legislation and provides preliminary provisions necessary to implement the entry into force of the law. In fact, what happened with the government political rotation was a new approach to the law. Rama government would approve an amendment in September to avoid a legal vacuum. Timely adoption of secondary legislation in accordance with the principles of law and its proper implementation is essential. As a result of this action, the general law on administrative procedures is pending. Implementation of the Law on Administrative Courts were postponed pending the entry into force of the Law on the Supreme Court, which is one of three laws necessary for obtaining candidate status (European Commission Annual Report, 20-25).

Implementation of the Law on the Organization and Functioning of Public Administration should take effect. Implementation of the Law on Inspections has made progress being adopted in February and includes provisions aimed at reducing the length and cost of inspections (p.28).

A very important element that is an indicator of the level of democracy in the country is the participation of the civil society in the political decision-making process. The report finds that the country's civil society is weak and fragmented. Also cooperation between state institutions and civil society remains low, especially at the local level. There is lack of transparency by the Albanian authorities in relation to the consultation with civil society, the frequency of these meetings and the time available. Admittedly, there is room for improvement, especially in rural areas (pg.30).

This reflection on the importance and influence of the civil society in the Albanian policy highlights the style and culture of the Albanian political decision making.

Reflecting on this detailed analysis of the report, there is a reluctance of political forces for inclusion and the transfer of duties and decision-making from central to independent institutions. This not only hinders the process of decentralization and impartiality but at the same time weakens the fragile democratic institutions.

\section{What do Europeanization and democratization mean?}

In order to properly understand the very long journey of the country towards the membership, it is very important to understand what Europeanization means. This would help me to compare the Albanian transition with the Europeanization process.

First, the process of Europeanization of a country has to do with the absorption of EU imperatives, how their logic operates logic and which are the norms in EU domestic policies (Anderson \& Eliassen, 1993). This means that in order for Albania to be considered a candidate member, Albanian policy making should embrace that philosophy and norms of policy-making European model offers. In other words, the EU offers inclusive model and cooperation between the parties in order that reforms can be achieved not simply by the will of actual current policy context of a particular government, but 
ISSN 2411-9563 (Print) ISSN 2312-8429 (Online)
European Journal of Social Sciences Education and Research
September-December 2014

Volume 1, Issue 2

has continuity despite the political rotation. The reform process should not intend an achievement of the coalition government, but as a national strategy for the improvement and adaptation of democratic institutions in the country. Respect for democratic values will allow further development of the country being supported and encouraged by the European community.

Secondly, Europeanization effects on excellence and improve the mechanisms of modernization to change specific policies, especially those dealing with macro-economic policy and also to reform political institutions. This means that the country should reflect that has all the elements to be considered a consolidated democracy. Although EU initiatives and international factors are not lacking, need necessarily to reflect a commitment not only breathe in the initiation of these mechanisms but above all in the implementation and in their succession.

What does consolidating democracy means? According to Linz \& Stepan, a country is democratic when "democracy is the only game in town right" (Linz \& Stepan, 1996). This means that they is has independent institutions in democratic and constitutional rules that define the game and not the will of a particular group, or even worse to a certain person. Democracies are considered when political actors are aware, committed and reflect the political will to compromise, which means the democratic regime rules (Ruston, 1970). This element is very important to better understand the situation properly and realistically in Albania which is divided and polarized by the political forces which do not reflect the culture of dialogue or even less political will to compromise.

In fact, consolidation or completion of the transition will only be achieved through compliance with rules and democratic procedures, or otherwise known as eight institutional guarantees of Dahl Poliarchy.

But specifically in Albania we can say that the period of adjustment toward democracy continues. To be concrete, the country is mired in a deep political crisis dominated by conflicting political dialogue which seems to keep mortgage the continuation of reforms.

Why is not functioning EU conditionality in Albania? At this point, I agree with the arguments that Kubicek offers. He asserts that the use of conditionality does not guarantee that changes claimed by the EU actually occur. Hence, he rightly raises the question of how and under what conditions can the EU conditionality can actually worked (Kubicek, 2003, 17). According to him, the initiatives of external actors have a greater political cost than can realistically be afforded by the political elite. Specifically, he argues that these initiatives will reduce the power of political elites at the time that the latter will be included in the process of democratization. Specifically, this dualism between political power and the continuation of the decentralization and de-politicization of state institutions manifests itself most clearly in the debate on public administration reform. De-politicization of public administration means that the political forces in power loses the ability to use administration as a means to satisfy its supporters (as has happened so far). Albania's public administration are radically changing periodically whenever changing political force that leads the government by increasing fictitious financial cost not only recruitment but also training every four or eight years as the government changes.

Kubicek argues that the government parties understand that they will lose their political power at the time that the country will be fully engaged in the execution of the process of democratization, thus they tend to push the application of democratic instruments even though they have to cope with external pressure, in case of negative feedback from Brussels (Kubicek, 2003).

Secondly, if we reflect political developments related to these last twenty years, we will see that the political elite are political actor with the current political ambitions. This means that in general the two main political forces have a shortterm agenda and as a result they try to exploit all opportunities to maximize the power in their hands and increase benefits or partisan purpose of their re-election in future elections. In this way they do not see immediate benefits from the implementation of European conditions. SAP implementation requires a multi-year commitment and it is not affiliated with the extra funds to offset potential losses of market opening with member countries of the EU (Hoffmann, 2005, 69). In this context, power is seen as a benefit and a way to achieve political ambitions of a certain spectrum.

Thirdly, the political culture in Albania is marked by the absence of dialogue and inability to generate a stable political climate. Ways of interaction between political parties leaves much to be desired and the parliament has become an arena of mutual accusations which remain only at the level of media and nobody is judicially accused for corruption or organized crime ties (last scandal that involves the Ministry of Defense) to the prosecutor. This model does not inspire trust and creates the premises for cooperation among parties, but in fact it has another negative effect: albanians confidence toward the rule of law is diminished and they do not see the judicial system as operative and functional.

Fourth, the process of EU membership is not viewed as a joint comprehensive strategy, but as a means of gaining credibility for a particular party and to secure the support of the electorate. As I mentioned above, all political forces in the 
country use the card EU campaigning to win the political battle in the name of democratic values, but it remains just a promise rotating unworn (Elbasan, 2004).

\section{Conclusion}

The path towards EU integration is associated with the consolidation of the democratic state and its functioning. The main condition for democratic consolidation is the development and strengthening of independent institutions that will enable and accelerate the fulfillment of the Copenhagen criteria through transparency and meritocracy impartiality.

Although Albania has made some progress in some aspects, such as the adaptation of domestic law with the EU, the partly implementation of the suggestions and recommendations of Brussels, the integration process is a long one and has different challenges. As the European Commission report highlights, the government has huge challenges ahead as the fight against organized crime and corruption, de-politicization of the public sector, the implementation of reforms in the judicial system, the implementation of public administration reform, strengthening of institutions independent economic and financial implementation of the right of ownership, etc..

Therefore, the first thing that should the Government and the opposition be aware of is that it cannot hold the mortgage on the democratization of the country with sterile debates and narrow interests of the moment. Democratization of the country and building a complete functional system with independent institutions must necessarily go further toward the development of the country. The spirit of dialogue and cooperation, in particular on priority reforms are necessarily in order to open the way towards the country integration.

Second, the strengthening of the administrative and judicial system is an essential condition for the functioning of the rule of law. These two elements are fundamental not only to strengthen the level of democracy in the country, but are essential to the development of a state that claims European integration.

Third, embrace democratic values and acceptance of the rules of the game of democracy. Being part of the European community means being a country with high standards not only economic, but social and cultural policy.

\section{References}

[1] Andersen S. \& Eliassen K. (1993). Making Policy in Europe: Europefication of National Policy-making. Sage Commission staff working document

[2] Albania 2013 Progress Report, retrieved from http://ec.europa.eu/enlargement/pdf/key_documents/2013/package/al_rapport_2013.pdf

[3] Elbasani A (2004). Albania in Transition: Manipulation or Appropriation of International Norms? Southeast European Politics, Vol V, No. 1 , pp 24-44.

[4] Featherstone, K. (1998). Europeanization and the centre periphery, South European Society and Politics, 3 (1). pp $23-39$

[5] Grabbe, H. ( 2002). The EU's Transformative Power, Europeanization through conditionality in Central and Eastern Europe. Palgrave Macmillan

[6] Hoffmann, J. ( 2005). Integrating Albania: the Role of the Europian Union in the Democratization Process, Albanian Political Science Association. pp 55-73

[7] Huntington, S. ( 1991.) Third Wave of Democratization. International Studies Institute

[8] Keshilli i Bashkimit Europian, Takimi i Tretë i Këshillit të Stabilizimit dhe Asocimit mes Shqipërisë dhe BE, Bruksel 19 korrik 2011,

[9] Konkluzionet e Presidencës, Këshilli Europian i Kopenhagenit 1993, retrived http://www.europarl.europa.eu/enlargement/ec/pdf/cop_en.pdf

[10] Kubicek, P. (2003). The European Union \& Democratization. Rutledge

[11] Linz J. \& Stepan A. (1996). Problems of Democratization, Transition and consolidation". John Hopkins University Press

[12] Rustow D. ( 1970). Transition to Democracy: Toward a Dynamic Model, Comparative Politics 2. Pp 337-363

[13] Schmitter , F. (1996). What Democracy is ... and is not, Journal of Democracy. N 3. Baltimore: Johns Hopkins University Press. 